\title{
Beregnyei József
}

\section{A rendvédelmi szervek (rendőrség) végrehajtó állományának utánpótlása és a korosztályi jellemzők viszonya}

\section{The relation between the supply of the executive staff of the law enforcement organisations (police) and certain age group characteristics}

\begin{abstract}
Absztrakt
A címben szereplö téma kapcsán abból indulok ki, hogy relatíve a tisztképzéshez, a vezetői felkészítéshez képest méltatlanul keveset foglalkozik a szakirodalom is a végrehajtó (tiszthelyettes) állomány utánpótlásával, helyzetük elörejelzésével, gondjaik megelőzésével. A rendőrség szervezetének jelenében éppen a tiszthelyettesi állomány utánpótlása az, amely számszerüsíthetően nagyobb gondot jelent - hiszen a leszerelők létszáma meghaladja a jelentkezők létszámát, s azt még nem is vettük számításba, hogy a szervezettől többéves, néha évtizedes szakmai tapasztalattal távozók tudása és gyakorlata nem pótolható pusztán a létszám meglétével. Jogosan merül fel a kérdés az olvasóban, hogy miért, mi ennek az oka? De azt is érdekes lenne megtudni, hogy a már állományban lévő tiszthelyettesek/zászlósok (továbbiakban altisztek) egy része - nyilvánvalóan, akiknek felsőfokú állami és szakmai (rendészeti szervező) végzettsége van miért szeretne továbbtanulni a Nemzeti Közszolgálati Egyetem adott szakán, hogy tiszt legyen belölük?! Hozzáteszem, ilyen paraméterü altisztekből elég sok van a rendvédelmi - különösen a rendöri - szervezeteknél. Lehetne rá egy nagyon egyszerü válasz: mert szeretnének előre jutni, jobban fizetö, inkább vezetői munkakörben dolgozni. De ennek csak ez lehet az útja? Mindezekre - és egyéb később érintendő tényezőre - tekintettel gondolom, hogy nagyon időszerü lenne a végrehajtásban dolgozó beosztott (tiszthelyettes) állomány helyzetével, utánpótlásával, munkakörülményeivel olyan mélyen, tudományos alapon foglalkozni, mint ahogy ez fennáll a tiszti állomány esetében.
\end{abstract}

Kulcsszavak: rendvédelmi szervek, végrehajtó állomány, a rendvédelmi szervezetek főbb jellemzői, korosztályi jellemzők, a végrehajtó állomány (tts., zls.) utánpótlása, az Y, Z generáció és a rendvédelmi szervek főbb jellemzőinek öszszevetése, megoldási/finomítási lehetőségek. 


\begin{abstract}
Regarding the topic indicated in the title, I assume that - compared to the issue of training commissioned officers and would-be leaders -, there is relatively little discussion going on about the workforce supply of the executive (warrant officers) staff, the prediction of their situation, the prevention of their problems, and this applies to special literature. In the current situation of the police organisation it is precisely the recruitment of warrant officers that is more of a problem - since the number of decommissioners exceeds the number of candidates, and we have not even taken into account that the knowledge and practice of those who leave the organization with many years, sometimes decades of professional experience, cannot be replaced by the mere presence of staff. It may well be asked: 'Why is this happening?' Also, it would be interesting to know why the warrant officers who are already members of the staff (obviously those who have already graduated from state or law enforcement higher education institutions) want to study further at a given specialisation of the National University of Public Service to become commissioned officers. Additionally, there are quite a huge number of warrant officers with these parameters in law enforcement bodies, especially police organizations. The answer could be very simple: they want to get ahead, to work in a better paying, working in a more managering position. But can this be the only way? Taking all this into account, I think it would be very timely to deal with the status, recruitment and working conditions of the subordinate (executive) staff working in the implementation as deeply as scientifically as it does for the officer.
\end{abstract}

Keywords: law enforcement organisations, executive staff, major characteristics of law enforcement organisations, age group characteristics, recruitment of the executive warrant officers' staff, comparison of the main features of the Y, $\mathrm{Z}$ generation and law enforcement organisations, options for refinement.

\title{
Bevezetés
}

Jelen írás megszületését több, a rendvédelmi - különösen a rendőrségi - szervezetek utánpótlásával kapcsolatos hagyományos és digitális újságcikkek indukálták. Nagy érdeklődéssel olvastam Tegyey Andrea által a Rendőrségi Tanulmányok I. évfolyam 2018/3 számában: A Z generáció címke - Jogos félelmek vagy lehetőség a megújulásra? címü írását. (Tegyey, 2018) Az utolsó lökést gondolataim írásba öntésére az adta, amely már azt feszegette, hogy amennyiben ennyire kevesen jelentkeznek a végrehajtás szintjén tevékenykedő rendőri tiszthelyettesnek, akkor minek kell négy rendészeti szakgimnázium ebben az országban? 
Nem volna szabad felcserélni az okot az okozattal. Attól, hogy bezárnának iskolákat az előbbiek közül, attól megnőne a rendőri pályára jelentkezők száma? Nyilvánvalóan nem. (De ha mégis így lenne, akkor pedig a visszaállt korábbi helyzet miatt szükség lenne rájuk.) Inkább azokat az okokat lenne célszerủ objektíven - előre kimondott megrendelői végeredménytől függetlenül - megvizsgálni, hogy mi az oka annak, hogy főleg a mai fiatalok számára nem vonzó ez a pálya, miért csak kevesen akarják e szakmát hivatásuknak választani a mai korosztály tagjai közül!? Jelen írásban ezekhez, illetve ezekkel kapcsolatban szeretnék néhány gondolatot megosztani a tisztelt olvasóval. A mondanivaló a jelenlegi és jövőbeni helyzetre, a mai fiatalabb generációkra vonatkozó információk, gondolatok közreadását, viták, részmegoldások indukálását próbálja megcélozni. Mindezt úgy, hogy benne, az utóbbi időbeni tapasztalatokra és a kapcsolódó (Y és Z) korosztály markáns jellemzőire alapoz. Úgy gondolom, hogy az ezekkel kapcsolatos megállapításokból kellene helyes következtetéseket levonni a jelenlegi és a középtávú időszakra vonatkozóan. Rögtön hozzáteszem, hogy a jelenlegi és a középtávú helyzetre vonatkozó lehetséges válaszok nemigen vannak teljes fedésben. Azért nem, mert az elkövetkezendő 2025-ös, de főleg a 2050-es évekről - amikről még csak feltételezéseink lehetnek - más tényezők, akkori lényegesen eltérő elvárások, lehetőségek, viszonyok kapnak majd nagyobb hangsúlyt a válaszok megfogalmazásában.

Kezdem egy alapigazsággal, amely szerint adott szervezet müködésének, eredményességének egyik legfontosabb tényezője ma - és még egy darabig mindenképpen - az emberi tényező. Az ott tevékenykedő személyek tudása, tapasztalata, egyáltalán minősége, amely az adott szervezeti vagyon része, szervezeti stratégiai erőforrás. (Szakács, 2015) Hiába a drága marketing, a jó rendezés, ha a kívánt általános- vagy szaktudással, módszertannal bíró, dolgozni akaró kimüvelt emberfők hiányoznak, akkor ez érzékelhetően kedvezőtlen hatással bír. Az emberi erőforrásokkal történő mindennapi foglalkozás célja megfelelő számú és összetételű munkaerő biztosítása a szervezeti célok eléréséhez kellő időben, helyen, adott munkakörökben. Napjainkban a munkaerö - különösen a kívánatos minőségü - megszerzése, megtartása már nem könnyü, kevésbé egyszerü, sablonos dolog, jelentős befektetést, odafigyelést igényel nemcsak a humán szakterület, hanem az egész szervezet és azok tagjai részéről egyaránt. A fejlett világ - benne hazánk is - általános problémája a társadalmak elöregedése, az első gyermek vállalási idejének kitolódása, a vállalt gyermekek átlagos számának csökkenése. Ebböl - ha nem történik pozitív változás - logikusan következik, hogy elöállhat az a helyzet, amikor több foglalkoztatottra van szükség, mint ahány alkalmas vállalkozó van a munkaerőpiacon. Később, a 2050es években már más lesz a helyzet, hiszen a mesterséges intelligencia (MI), a 
digitalizáció ${ }^{1}$ és a robottechnika kiválthat bizonyos - főleg fárasztó, monoton - élőerős részfunkciókat, amit az MI egyszerübben, biztonságosabban old meg. Csakhogy a rendvédelemnek nemigen van olyan ága, amely kiváltható lenne ez által, ugyanakkor mindez nem eredményezi automatikusan azt, hogy a szervezet vonzóvá válna a fiatalok számára.

Ez nem csak a munkaerő utánpótlásra, hanem a munkaerő megtartásra vonatkozó kihívást eredményez már napjainkban is. Ebből adódóan meg kell találni azokat a motivátorokat, ki kell alakítani, megreformálni azokat az optimális körülményeket, belső munkaviszonyokat, amelyek révén a fiatalok országon belüli maradásra, a fegyveres rendvédelmi pályán történő munkavállalásra bírhatók.

\section{A rendvédelmi szervekhez beosztotti hivatásos szolgálatra jelentkezőkre vonatkozó megállapítások}

A fejezetcím kapcsán egy vagy több kérdés is felmerülhet. Egyik ilyen, hogy van-e elég számú pályázó fiatal erre a már csupán „élethivatásnak” nemigen tekintett, a rendvédelmi szerveknél létesített végrehajtó szintü - rendőr, tüzoltó, büntetés-végrehajtási tiszthelyettesi - szakmákra? A másik az lehet, hogy van-e eltérés a tiszti- és a tiszthelyettesei utánpótlás alakulásában?

Amennyiben öszinték akarunk lenni, akkor egyértelmüen el kell ismerni a rendvédelmi szervek - kiemelten a rendörséghez - végrehajtó szolgálatra pályázó fiatalok köre - az intenzív toborzás mellett is - fokozatosan csökken. Persze a Magyar Honvédség sincs könnyebb helyzetben, annak ellenére, hogy az ottani hasonló tiszthelyettes fizetés az illetményalapjuk miatt kissé magasabb. Amikor utánpótlásról beszélünk, mást-mást kell érteni a rendvédelmi szakgimnáziumi pályázók és felvételt nyertek között. Ugyanis, a ténylegesen bekerülők száma a szakképzésbe a jelentkezők számához képest legalább 20-40\%-al $k^{k} v_{e s e b b}{ }^{2}$. Öt év alatt közel negyedére esett vissza az ország négy rendészeti szakgimnáziumában a jelentkezők száma. Míg 2014-ben 3060-an, 2018-ban már csak 1715 -en jelentkeztek, az idén pedig alig 880 fiatalnak volt ilyen szándéka ${ }^{3}$. Az elkövetkező években összesen tartósan cirka 1200 új elsőéves tanulót

1 A digitalizációban elöttünk járó országok repülőterein bizonyos utaskategóriák esetében teljesen automatizált be és kiléptetés folyik, felszabadítva ezzel az élő munkaerő jelentős részét.

2 A 2000-s években minimum 2-3 szoros volt a jelentkezők száma a felvehetőkhöz képest.

3 Természetesen ez szoros összefüggésben van a rendörség határvadász állományának a feltöltésével, amely jelentős mértékben elszipkázta a nappali képzés elől a jelentkezőket, hiszen anyagilag összehasonlíthatatlanul jobb feltételeket biztosított a rendőrség az ide jelentkezők részére. De ne felejtsük el, hogy határvadász képzésben részt vettek, csak rész szakképesítéssel rendelkeznek, kiknek további képzésére a Rendészeti Szakgimnáziumok jogosultak. 
kellene felvenni a szakgimnáziumokba, hogy legalább a minimálisan elvárható létszám - legalább az avatás utáni első 2-4 évben - stabilizálódjon. Nincsenek ilyen gondok a felsőoktatásban, az NKE rendészettudományi kar bármely szakán. Itt is észlelhető csökkenés, de még folyamatosan többszörös a jelentkezők és a felvehetők létszáma. Érdemes lenne megvizsgálni, hogy a középfokon tapasztalt gond miért nem érezteti hatását a rendvédelmi felsőoktatás szakirányain.

Mi lehet az előbbi kérdésekre adott közléseim alapvető okai, befolyásoló körülményei? Vajon miért csökken a rendvédelmi pálya iránti vonzódás akkor, amikor országosan a civil középiskolák közül több, olyan jellegü felkészítéseket - Rendészeti ör, Rendészeti ügyintéző, Közszolgálati ügykezelö, Közszolgálati ügyintéző, Belügyi rendészeti ismeretek - szervez, amelyek előszobái lehetnének a fegyveres rendvédelmi pályára készülésnek.

Az okokat, befolyásoló körülményeket két csoportba - úgymint objektív és szubjektívekre - lehetne rakni. Az okok nagy része objektív, először ezeket érintem. Sajnos az ország népessége, ezen belül az érettségizettek száma fokozatosan szükül ${ }^{4}$, de ami ezután várható a körülményekben az sem kedvezö. A KSH elemzései a következő cirka 40 évre vonatkozóan ezeket valószínűsíti: 2 millió fövel csökkenhet a népességszám, minden harmadik ember 65 évnél idősebb lesz, a gyermekvállalás halasztása és a gyermektelenek aránya növekedni fog ${ }^{5}$. (Monostori - Öri - Speder, 2018) Az intézet szakértői által készített népesség-előreszámítás szerint 2060-ban várhatóan 7,9 millió fő körül alakul Magyarország népessége, vagyis a következő 40 évben közel 2 millió fővel fogyatkozunk. De mitől is függ alapvetően az ország lélekszámának konkrét mennyisége? A népesség számának alakulása három tényezőtől függ: az élve születések (ez pedig a szülöképes korú nők számától és gyermekvállalási hajlandóságuktól), halálozások és az elvándorlások, kivándorlások, a nemzetközi migráció (vándorlás) egyenlegétől. Ezekkel - bár megérné bővebb körüljárásuk - itt és most nem kívánok foglalkozni, mivel ez nagy terjedelmü írást eredményezne. Azzal sem, hogy milyen ma a magyar állampolgárok korfája, de azt megemlítem, hogy közismerten két nagy születési évjárat kiugróan népes csoportja létezik. Az egyik az 1950-s ún. Ratkó korszak szülöttei, a másik pedig az 1970-es években (a GYES bevezetése következtében) születettek, lényegében az előbbiek gyermekei. Ök sokkal többen vannak, mint az őket megelőző, illetve őket követő évjárat tagjai. Míg az előbbi korcsoport tagjai 2018-ra már elérték a nyugdíjkorhatárt, a másik pedig most a korfa középkategóriáját erö-

4 Az Oktatási Hivatal adatai ezeket a számokat mutatják: 2015-ben 115 300, 2016-ban 112 000, 2017 ben 108500 és 2018-ban pedig 110700 fő érettségizett.

5 Ez csak néhány kiemelés a KSH Népességtudományi Intézet által készített 2015-ös Demográfiai Portré tartalmából. 
sítik, cirka 25-30 év múlva ők is nyugdíjas korba jutnak. Nyilvánvalóan az országos adatok valamilyen mértékben a rendvédelmi szervek, a rendőrség ${ }^{6}$ humán erőforrás-gazdálkodására is kihatnak. Ennek ismeretében, most nézzünk rá a rendőrség 2010-2016 közötti ${ }^{7}$ néhány főbb mutatóira, általában a hivatásosokra, és ezen belül az altisztekre fókuszálva. (Bittner - Kehl - Szőcs, 2013) A KSH adatai szerint ${ }^{8}$ a rendőrségi tiszti kar létszáma 2013-tól kezdődően fokozatosan növekedett a rendszeresített létszámhoz képest.

\begin{tabular}{|l|r|c|c|c|c|c|c|}
\hline Tiszt. & -669 fö & +290 fö & +310 fö & +373 fö & +667 fö & +490 fö & +655 fö \\
\hline Tths. zls. & -656 fö & -670 fö & -690 fö & -709 fö & -550 fö & -415 fö & -2465 fö \\
\hline ÉV & $\mathbf{2 0 1 0 .}$ & $\mathbf{2 0 1 1 .}$ & $\mathbf{2 0 1 2 .}$ & $\mathbf{2 0 1 3 .}$ & $\mathbf{2 0 1 4 .}$ & $\mathbf{2 0 1 5 .}$ & $\mathbf{2 0 1 6 .}$ \\
\hline
\end{tabular}

Tiszti állományúból csak 2010-ben volt hiány (669fö) a rendszeresített létszámhoz képest, az ezt követő években 2016-ig bezárólag 370-700 közötti többlet volt ebböl a kategóriából. Ezzel szemben az altisztek köre 2010-töl kezdve évente cirka 415-700 fö közötti hiányt mutatott, ami 2016-ban már 2.465 före emelkedett, s az óta sem sikerült teljesen megszüntetni még a legújabb - a Készenléti Rendőrség határvadászaihoz kerülö - őr-járőrtárs rész-szakképesítésủekkel sem. Egyébként a rendőrség teljes hivatásos állományúak száma 2015 végén 37.241 fö-, amelynek megoszlása 25.551 fö altiszt -, és 11.690 fö tiszt volt.

De az okok között nem szabadna elhallgatni azokat sem, amelyeken - megfelelő akarattal - lehetne és kellene is változtatni! Ezekre később térek ki!

A rendőri létszámhelyzet kapcsán mindig felmerül az is, hogy ez itthon kevés, sok, avagy elég? A rendőrök száma az egész Unióban 2016-ban 1,6 millió volt, ez 3,4\%-os csökkenést jelent a 2009-es létszámhoz képest. Ha kifelé viszonyítunk, akkor kiderülhet az, hogy itthon 100 ezer före 90 rendőr jut, miközben az Európai Unió átlaga 318. (2016. évben ez utóbbi 316 volt.) Magyarországot Finnország követi, ott 137 rendőr jut százezer emberre, a dánoknál pedig már több mint kétszerese a magyarnak, 186. A visegrádi országok közül a lengyeleknél 263, a cseheknél 383, a szlovákoknál pedig 410 az arányszám.

6 Konkrétan csak az általános rendeltetésű rendőrség ilyen jellegü helyzetével foglalkozom a továbbiakban.

7 Azért csak erre, mert a 2016 utáni évekre sem a KSH, sem a Rendőrségi nem megjelenő Évkönyvei ilyet hivatalosan nem tartalmaznak. A Rendőrségnél pedig nemigen adnak ki adatokat, holott a nyitottság és az átláthatóság elvárható volna a társadalom részét alkotó jogvégrehajtó szervezettől is.

8 Magyar Statisztikai Évkönyv (2016): Budapest, Központi Statisztikai Hivatal, 406. A rendőrség létszáma. 


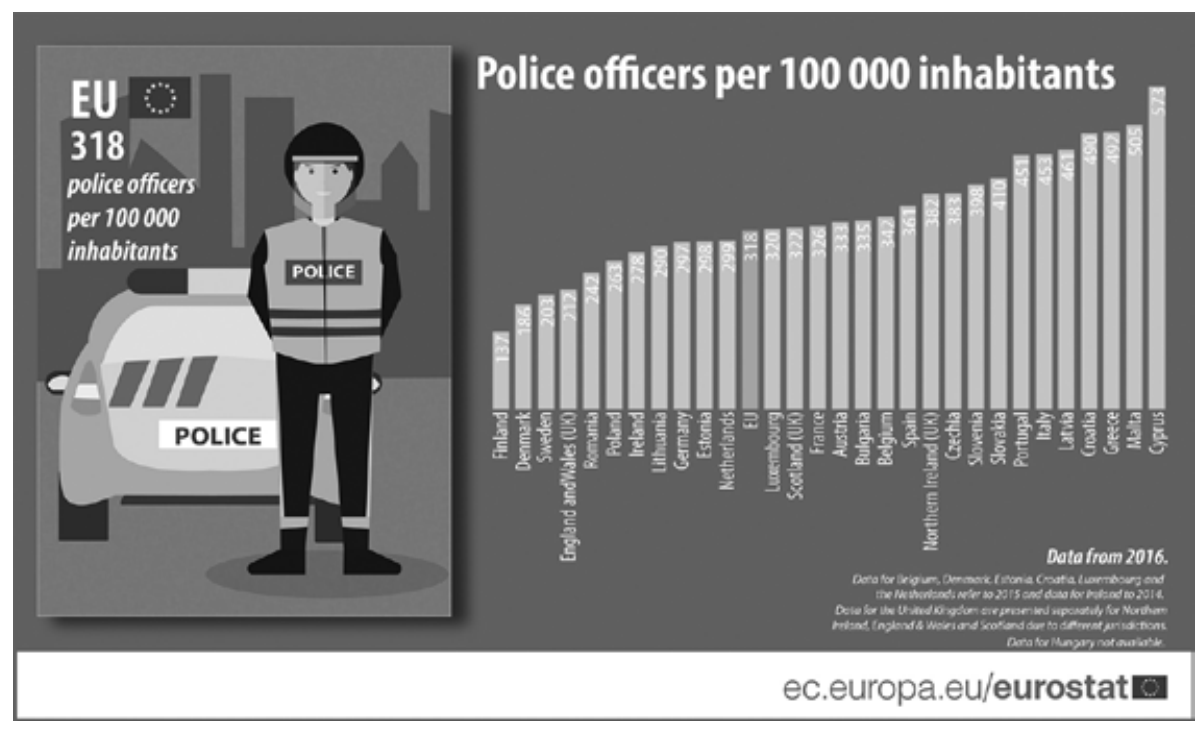

1. kép. 1.6 million police officers in the EU (URL1)

Tisztában vagyok vele, hogy ezen megnevezett országok gazdasági- bünügyi-operatív helyzete más-más, életviszonyaik, földrajzi helyzetük is eltérőek, ami kihat a létszám alakítására is. Ugyanakkor, ha a honi rendőri végrehajtók száma tovább fog csökkenni, akkor vagy sokkal több részfeladatot teljesítéséröl kell lemondani, avagy a meglévő állomány fog erősen túlórázni. (Ez pedig további leszereléseket vonhat maga után, hiszen olyan alapfizetésért kell többet teljesíteni, amelyet másutt - civilben - sokkal kisebb felelösséggel is megkereshet.) Ha pedig ezek pénzbeli megváltása elmaradna 2020 után, akkor magas kiválási létszámmal lehet kalkulálni! A túlóráztatás negatív hatását az egyénekre vonatkozóan nem részletezem. (Borbély - Fridrich - Tőzsér, 2018, 65-79.) Persze felmerülhetne a rendőri állomány területi elhelyezése, megosztása, szervezeti állománytáblájának - aluról felfelé építkező - felülvizsgálatának, vagy a részfeladatok sokkal koordináltabb megvalósításának gondolata is. (Borbély - Fridrich - Tözsér, 2018, 97-102.)

A következö kérdés az, hogy milyen átlagjellemzökkel rendelkeznek a témánk szempontjából szóba jöhető mai (Y, Z) generáció tagjainak többsége és ehhez képest mik a szakma, a vezetés rendőrségi pályakezdőkkel szembeni érvényes jelenlegi elvárásai?

Ahhoz, hogy erre az összetett kérdésre vonatkozó véleményemet kifejtsem egy nagyobb kitérőt szükséges tenni, ugyanis a válaszok közreadása előtt szólok röviden a generációkról általában, a két korosztály jellemzőiről, a szakmaután- 
pótlással szembeni jelenlegi elvárásokról, majd pedig mindezek összevetését követően vonom le az általam fontosnak ítélt következtetéseket.

\section{Általában a generációkról}

A magyar értelmező kéziszótár szerint a nemzedék vagy generáció; „Egy korban élö és kb. azonos korú emberek összessége" ". E kifejezést biológiai értelemben is használjuk, amikor az egymást felváltó utódok életének időszakáról beszélünk. Napjainkban a generáció fogalmát sokkal inkább szociológiai, semmint biológiai szempontból érdemes megközelíteni. Ebben az értelemben a generáció olyan személyek csoportja, akik ugyanabban a korszakban születtek, akiket sajátos események, trendek és folyamatok alakítanak és kötnek össze (Töröcsik - Szücs - Kehl, 2014, 23-45.). Elméletileg tehát azt jelenti, hogy a kortársak történelmileg azonos korszakban és földrajzilag azonos helyen élnek, valamint hasonló értékeket képviselnek. Mialatt a különböző életkorú személyek ugyanazon eseményeket élik is meg, az életkor, amelyben egy-egy eseménnyel, technikai, vagy társadalmi változással szembesülnek, meghatározza, mennyire épül be az adott tényező az ebben érintett személy pszichéjébe és világlátásába. Bár igaz lehet az is, hogy a követő generációk bizonyos dolgokat tradícióként átvehetnek az előző korosztálytól, de a teljes körü ismétlődés szinte kizárt. Az általános politika, a technika, a technológia, a tömegmarketing, a populáris kultúra, amelyben napjaink fiataljai felnőttek/felnőnek, jelentős különbséget generálhatnak. A különböző korok, állapotok és társadalmi jelzések miatt a generációknak különbözőek lehetnek az elképzeléseik bizonyos dolgokról, a vágyaik, esetleg még a világlátásuk is más-más lehet.

Különösen érzékelhető ez napjainkban, amikor a gazdasági válság és utózöngéje, a klimatizációs viszonyok lassú, de érezhető változása a nagyvilágban, nagyléptékü technológiai innováció, a mesterséges intelligencia (MI) térhódítása, a globalizáció, a migráció megélénkülése, a népességcsökkenés a fejlett világban, a kivándorlás megerősödése lényegesen ható, alakító tényező lett. Hozzáteszem rögtön, hogy ez nem elsősorban csak generációs kérdés, hanem ennél sokkal komplexebb probléma, de hatása a generációkra, többek között a rendvédelmi szervek utánpótlására vonatkozóan megkérdőjelezhetetlen! (Tőzsér - Fridrich - Borbély, 2017, 119-127.)

A kapcsolódó irodalom - lásd az írás irodalomjegyzékében különösen Tegyey Andrea írásai - az alábbi korosztályokat nevesíti a háború utáni Európában: a

9 Magyar Értelmező Kéziszótár (1972): Budapest: Akadémiai Kiadó, 997. 
Veterán generáció (1925-1945 10); a Baby-boomer korosztály (1945-1965); az X generáció (1966-1980); az Y generáció (1981-1994); a Z generáció (19952010-es évek) és az Alfa generáció (2010-s évek - ...) ${ }^{11}$. (Nagy, 2017, 53-60.) Az elmúlt fél évszázad nagyon sok változást hozott/hoz, új kihívásokkal kell nap, mint nap szembenéznünk. Nem szabad viszont figyelmen kívül hagyni, hogy a generációkat egyének alkotják, saját személyiséggel, preferenciákkal és világlátással. Sőt ezen egyének földrajzi, kulturális és neveltetési háttere felett sem tekinthetünk el. Nem mindegy, hogy milyen családba született, hol nőtt fel, milyen iskolázottsággal bír valaki. További fontos tényező az életciklusuk alakulása. (Tegyey, 2018) A felnőtté válás bizonyos föbb mérföldköveken keresztül zajlik, amelyek akár gyökeres hatást is indukálhatnak az egyének további életében. Ezek; az első munkába állás (fóállás megszerzése), a lakhatás lehetősége, a párválasztás, a gyerekvállalás, a további kitüzött célok megvalósítását befolyásoló pénzügyi forrás megléte, avagy a hiánya. (Tegyey, 2018)

Már itt, még a következő alcím előtt kihangsúlyozom, hogy a generációkra vonatkozó kategorizálás az adott generációkra vonatkozó jellemzők nem mindig állják ki a konkrét vizsgálat próbáit, ezért én továbbra is nélkülözhetetlennek tartom az egyes személyek, egyének, kiscsoportok helyzetének, viszonyának, igényeinek, véleményeinek alkalomszerü felmérését és vizsgálatát. A generációk sokrétüek, ezért főleg olyan általános mutatókat lehet rájuk mondani, ami leginkább csak a többségükre igaz. Ezért is kérem, kezeljék a következő pontban leírtakat ennek megfelelően! Jogosan kérdezhetik meg azt, hogy akkor miért foglalkozom itt a generációkkal. (Tegyey, 2019, 234-241) Azért, mert a hivatásos tiszthelyettesi hiány dolgában sem tekinthetünk el ennek és ehhez kapcsolódó tényezőknek a mélyebb vizsgálatától, e jellemzők emberi erőforrásra vonatkozó hatásaitól. ${ }^{12}$

\section{Az Y és a $Z$ generáció főbb jellemzői}

A jellemzők taglalása során sok dologra lehetne kitekintést tenni. Közülük itt csupán azokat emelem ki, amikre érdemes lehet a rendvédelmi szervek illetékeseinek figyelniük. Megjegyzem, hogy a korosztályok teljes listájából talál-

10 A zárójelben lévő évszámok mutatják, az ebben az időszakban születettek korosztályi kategorizálását.

11 Az alfa generáció, mint önálló generáció létjogosultságát Nagy Ádám, Az Alfa generáció magyarországi recepciója c. cikkében vitatja.

12 Ha nem veszünk tudomást arról, hogy a generációk valamikben különböznek és a generációváltások lényegesen gyorsabban következnek be, akkor azok a szervezetek, amelyek jelentős humán erőforrással dolgoznak, müködési problémákkal fognak szembesülni. A benne dolgozó munkatársak elbeszélnek egymás mellett, teljesen más probléma-megoldási lehetőségeket fognak találni, sőt teljesen mást fognak problémának és megoldandó feladatnak tekinteni. 
kozhatunk a rendvédelmi szervek hivatásos állományában az előttük álló Baby boom korosztállyal és az X generáció tagjaival is. Az Y és a Z generáció itt érintett jellemzőit a kapcsolódó, föleg magyar irodalom feldolgozásaiból, és az ide tartozó felmérésekből - lásd: felhasznált irodalom - emeltem ki, saját gondolattal kiegészítve. (Tegyey, 2018)

\section{Y generáció}

Ők már egy fogyasztói társadalomba születtek bele. Általában pörgős életet élnek. Az a generáció, akik törődő és gyereknevelésről sokat olvasó, és un. helikopter szülők mellett nőttek fel.

Gyakorlatiasan használják az IT és kommunikációs technikák alapeszközeit. Mivel a számítógépekkel együtt nőttek fel, remekül eligazodnak az interneten. Kevésbé jönnek zavarba, ha valami új technikát kapnak kézhez, nem jelent problémát számukra tájékozódni a felgyorsult világban, amely sok fals vagy csak részben igaz információval árasztja el őket.

Legtöbbjük magabiztos, agilis, kifejezetten tehetséges, kreatív személy, aki a korábbitól jelentősen eltérő viselkedést mutat a tanulás és a munkavégzés területén. Nyilvánvalóan ezek fiatal életkorukra és az aktuálisan átélt életszakaszukra vezethető vissza. (Tari, 2010)

Társadalmi kapcsolataikat egy időben, egyszerre élik meg a valós és a virtuális világban.

Leginkább az egyén szabadságát, a formalitásmentes közvetlen világot méltányolják.

A jó fizetési elvárásokon felül, fontos számunkra a munka és a magánélet egyensúlya, szabadidejük nagy érték számukra. Sokan megpróbálnak egyensúlyozni munka és karrier között, de mivel nincs korábbi minta arra, hogy ezt hogyan is lehet véghezvinni, nő a belső bizonytalanságuk. Többségük a munkát szervezi az életéhez, és nem fordítva.

Olyan munkát kívánnak végezni, amit szeretnek is. Öntudatos munkavállalók, ha nem tetszik valami, nincsenek valamivel megelégedve, akkor odébbállnak, ezt minden különösebb érzelmi trauma nélkül teszik. Mivel sokan közülük több nyelvet beszélnek, az ország határai sem kötik őket.

Élvezni akarják a munkahelyet, mint helyszínt: legyen az modern, a hagyományostól eltérö, nagy tág terekkel, és közös étkezésre, beszélgetésre lehetőséget adó konyhával. Fontos lehet ennek esztétikája, atmoszférája. Nem a hagyományos irodai munkakultúrát képviselik, hanem a mobilt, amivel már természetes a távmunka és az egyéni munkaidő-beosztás is. 
Keresik a lehetőségeket, bevethető tudás elsajátítására törekszenek és gyors elörehaladást igényelnek. A legfontosabb tudást, amely a digitális újkorban szükséges, nyilvánvalóan nem az előző generációktól szerzik meg, hanem saját maguk által és kortársaiktól. Sőt, nem hogy nem tőlük tanulják meg, hanem esetleg ök tanítják az előző generációk tagjait a digitális világ eszközeinek használatára. Tehát az úgynevezett fordított szocializáció is megjelenik már esetükben (Kissné, 2014).

A munkaerőpiacon komoly kihívást jelentenek az X generáció számára, mert minőségileg új szintet képviselnek azokhoz képest. Elődeiket megszégyenítő önbizalommal szállnak szembe a megkövült szabályokkal, más képességekkel is rendelkeznek, mint az elöző generációk. ${ }^{13}$

Nem mellékesen jegyzem meg, hogy Ők már nem voltak sorkatonák.

Szándékom szerint a $Z$ generációt kicsit bővebben érintem, mivel nagyszámban történő megjelenésük a munkaerőpiacon meglehetősen az elején tart. Ugyanakkor első képviselői - sajnos nem elég számban - már ott ülnek bent a rendészeti szakgimnáziumok, valamint a NKE Rendészettudományi Kar iskolapadjaiban. A 2018-as évben a rendészeti oktatási intézmények jelentkezői között már olyanok is voltak, akik a millennium idején látták meg a napvilágot.

\section{Z generáció ${ }^{14}$}

Nagymértékben különböznek az elmúlt több száz év generációitól, hiszen ök a világ első globális nemzedéke, ugyanis a terrorizmus krízisperiódusában, a globális válság (Sallai, 2013, 37-41.) és a klímaváltozás idején születtek, egy olyan korban, amikor sem a problémák, sem a trendek nem ismernek határokat.

Egyenesen a digitális világba születtek bele, ők azok, akik - kis túlzással - lehet, hogy még nem dobták el a cumijukat, de már egérrel és billentyüzettel is játszadoztak. Ennél fogva vérükké vált a technika, a különbözö kommunikációs eszközök használata. Információforrásuk is leginkább a Web. Magától értetődőnek találják, hogy minél gyorsabban jussanak hozzá naprakész információkhoz, még ha a hiteles információk kiválasztása és a kritikai gondolkodás problémát is okozhat nekik. Tökéletesen akklimatizálódtak a videojátékok szemkápráztató tempójához és az azonnalisághoz, talán ebből adódik a türelmetlenségük is. (Tari, 2017)

Hozzászoktak ahhoz, hogy állandó kapcsolatban vannak egymással, korlátlan és azonnali hozzáférésük van a világhálóhoz. Hálózaton keresztül funkcionál-

13 Gondoljunk bele: ennek a korosztálynak akarjuk a szolgálati törvényünkben, elöljárói intézkedéseinkben elrendelni, hogy mobil telefonját tartsa az öltöző szekrényében. Mintha nem vennénk tudomást a világ haladási irányáról.

14 A jellemzőkből az itt szerepeltettek kiemelése - tekintettel a 4. pont tartalmára - tudatos részemről. 
nak a legjobban, még a szocializációjuk is virtuális térben történik. Esetükben az offline kapcsolat háttérbe szorul az online-nal szemben.

Nemcsak profin kezelik a legfejlettebb elektronikus eszközöket, sőt egyszerre többet is használnak, több funkcióval. Jellemző rájuk a párhuzamos cselekvés, ismerős lehet az, amikor a gyerek egyszerre tanul, eszik és blogol. Ez a generáció mindezekre a készségekre az iskolán kívül, szabadidejében tesz szert, kizárólag önszabályozó módon, illetve hálózatban kortársaitól tanulva. Az online világ kitágítja énjük határait, és alakítja identitásukat. A közösségi oldalak egy új lehetőséget biztosítanak arra, hogy minél több embernek és minél gyorsabban öntsük ki a lelkünket. ${ }^{15}$ Idejük nagy részében alkalmazzák a különféle programokat, technikai jellegü közösségi fórumokat, miközben a klasszikus tömegmédiumokra (televízió, rádió) kisebb figyelmet fordítanak.

Bátrak, kezdeményezők, kevésbé motiváltak, nemigen kételkednek saját képességeikben és korlátaikban, praktikus szemléletüek. Ebben hasonlítanak az Y generációra. Nagyra értékelik a formalitásmentes közvetlen környezetet. Bizonyos ügyekben kritikusak, és kevés modellt fogadnak el maguknak. Nem kedvelik az autoritást, viszont élvezik a függetlenséget, a személyes szabadságukat. (Ferencz - Szabó, 2012)

A többségük tudatosan tervezi életét, a tanulás és a karrier - föleg az utóbbi - iránt fogékonyak, de olyanok is vannak közöttük, akik várják, hogy a karrier találja meg őket. Ök már nem egyénileg fogják forradalmi ötleteiket megvalósítani, hanem egymással összefogva szolgálják a közösséget. Mások gondjaival kapcsolatban nem mindig empatikusak, segítókészek. (Tari, 2011)

Ha kíváncsiak valamire, azt kevésbé a könyvekben, hanem interneten néznek utána, mivel a Google a legjobb barátjuk. Ehhez kapcsolódik az, hogy kevésbé szeretnek elmélyülni egy bizonyos témában, érdeklődésük sokkal inkább nevezhető szerte ágazónak, avagy részlegesnek. Figyelmük így nehezen köthető le, rövid, tömör, lényegre törő magyarázatokat, ész érveket, instrukciókat, és leginkább képi megjelenítéseket fogadnak be könnyebben.

Többségük számára a munkahelyek cserélgetése már nem meghökkentő, hanem természetes dolog. Lelkiismeret-furdalás nélkül odébbállnak, ha szükségét érzik, nem ragadnak le egy-egy foglalkoztatónál, nem aggódnak amiatt, hogy adott pillanatban nincs biztos fizetésük, állásuk. ${ }^{16}$

15 Ennek megvan a jó és rossz oldala egyaránt. Egyrészt az illető nagyon könnyen és nagyon gyorsan megkönynyebbül attól, hogy elsírja a bánatát a Facebook-on, az Instán, egy blogon, a Twitteren, Youtube-on stb. De: ehhez az információhoz illetéktelen emberek is hozzáférnek, nem csak a legjobb barátaik olvassák. Azt is sokan elfelejtik, hogy ami egyszer a netre kerül, annak nyoma marad még akkor is, ha kitörlik a posztot vagy a képet.

16 Bár ez összefügghet azzal is, hogy nincs olyan felelősségük, amely miatt ezen aggódniuk kellene. Ugyanakkor fontos tendencia - hiszen már az Y generáció esetében is megjelent - és a szervezetnek figyelnie kell(ene) rá. 
Már az iskolákban is jól megfigyelhető, hogy a tanár a szemükben messze nem a tudás kizárólagos birtokosa, társaiktól, fórumokból előbb kérdeznek, mint tőlük. Ez fennállhat a közvetlen vezetőjük, felettesük tekintélyének el(nem)ismerése terén is.

Náluk is prioritást élvez a munka és magánélet egyensúlyának megteremtése. ${ }^{17}$

Fontos számukra az újdonság, a kaland, így nem meglepő, hogy nem szeretik a monotonitást.

Fogyasztói attitüdjeik nekik is erősek. A fizetésen túl a munkahely komfortja esetükben sem mellékes. Elsőbbséget élvez részükről a boldogság.

Fontos számukra a szépség, úgy érzik, vonzó külső nélkül nem lehet előre jutni az életben. Féltik az egészségüket, sokat tesznek a testükért, és az ehhez vezető utat könnyedén megtalálják a neten. Ha valami betegségi tünetet észlelnek magukon, erre vonatkozó választ is a neten keresik.

\section{A szervezeti elvárások és a korosztályi jellemzők összevetése, valamint ezek alapján történő lehetséges teendők}

Ezek után nézzük meg, vajon mi a jellemzője az általános rendeltetésú rendőrségnek szervezeti szempontból, milyen elvárásai volnának a hivatásos tiszthelyettesi állományát illetően. A rendőrség rendeltetésével, feladataival itt nem kívánok foglalkozni, bár minden egyébnél ezekből kell kiindulni.

\section{Rendvédelmi elvárások érzékeltetése}

Közismert az, hogy rendörség szervezetén belül a végrehajtásban dolgozók különféle szolgálati ágakban, szolgálatokban és szakszolgálati csoportosításban végzik munkaköri feladataikat. Ezt csak azért említem, mert magától értetődően az azonosságokon túl, lehet más-más részelvárása a bünügyi, a közrendvédelmi, a határrendészeti vagy a logisztikai területen tevékenykedő, sőt a főváros adott kerületét, avagy a tanyavilágot magába foglaló illetékességi területen dolgozó hivatásosokkal szemben. 2008. év január elsejével hivatalosan megtörtént a rendőrség és a határörség integrációja ${ }^{18}$ megkezdte müködését az új

17 Bármely környezetböl képesek probléma megoldást importálni, és azt a saját körülményeikre adaptálni. Ezek a megoldások pedig nem biztos, hogy rendvédelmi szervek mindennapjaival kompatibilisek lesznek.

18 Ezzel a témával foglalkozó konferenciára sor került a korábbi RTF-en az akkori föiskola és a MRTT, Határrendész szakosztálya szervezésében. 
felállású, összetételủ általános rendeltetésű rendőrség. A rendvédelmi hivatásos szolgálat teljesítését az önkéntes jelentkezés, a szolgálati érdek elsődlegessége, az érintett rendvédelmi szerv iránti közbizalom megóvása, a szigorú függelmi rend, az egyes alapjogok korlátozásának elfogadása, valamint az élet és a testi épség kockáztatásának lehetősége jellemzi. Ezek mind-mind szigorú elvárások. A rendőrség a jogállam alapvető intézménye, állami fegyveres rendvédelmi szerv. (URL2) Müködése során tiszteletben tartja és védelmezi az emberi méltóságot, óvja az ember jogait. Feladatai ellátása során együttmüködik az állami és a helyi önkormányzati szervekkel, a társadalmi és a gazdálkodó szervezetekkel, az állampolgárokkal és azok közösségeivel; segítséget nyújt - jogszabályban meghatározott esetben - az állami és a helyi önkormányzati szervek részére, támogatja a helyi önkormányzatoknak és az állampolgárok közösségeinek a közbiztonság javítására irányuló önkéntes tevékenységét. Feladatuk ellátása során pártbefolyástól mentesen járnak el. A rendvédelmi szervek müködése - így a rendőrségé is - parancsadásra és annak végrehajtására, a szolgálati út betartására, valamint a szolgálati és a szakmai alá-fölérendeltségre épül. A vonatkozó törvényhelyhez kapcsolódó részletes jogosultságokat, illetve kötelezettségeket, a szolgálati érintkezés és az udvariasság alapjait, a jelentések és a jelentkezések rendjét belső szabályzatok rögzítik. Az alakiságra, az állampolgárok eligazodását is segítő egységes megjelenésre, a hivatásos állomány tagjával szemben elvárt fegyelmezett munkavégzésre vonatkozó speciális elvárásokat is úgyszintén jogi eszközök tartalmazzák. A szervezeti kultúrához is kapcsolódó etikai elvárásokról, a fegyelmi felelősségvállalással, az összeférhetetlenséggel, a méltatlansággal kapcsolatos szabályokról is célszerủ említést tenni. Mindezek alapján kimondhatjuk tehát; a rendvédelmi szervezetek derékhadát adó hivatásos állományúakra, valamint az új keletü rendészeti igazgatási alkalmazottakra kiemelt elvárások, követelmények illetve jogosultságok vonatkoznak.

Milyen elvárások léteznek az általános rendeltetésű rendőrség a közterületen dolgozó altisztjeivel szemben.

Magától érthetően már a szervezetbe is csak olyanok kerülhetnek be - illetve dolgozhatnak ott - akik büntetlen előéletük, megbízhatóságuk, életvitelük kifogástalan, pszichikai, egészségügyi és fizikai állapotuk, erőnlétük megfelel a vonatkozó standard követelményeknek. További elvárás a fegyelmezettség, egyértelmü parancsvégrehajtás, engedelmesség, a permanens önképzés, az IKT és más korszerü technikai eszközök alkalmazásának készsége (technológiai hozzáértés) a rendőri munkában. 
A rendészeti szakgimnáziumok még szakközépiskolai időszakukban aprólékosan foglalkoztak a kompetenciákkal, a kompetencia alapú felkészítéssel. Ehhez különféle felméréseket, vizsgálatokat végeztek már az 1990-es évek közepén. Ezek alapján szerepelnek a képzési alapdokumentumokban jelenleg is a kívánatos - a felkészítés során megcélzott - kompetenciák listája. Ezekről a rendőri szakképesítések esetében a vonatkozó Szakmai és Vizsgakövetelményekben, valamint a Képzési Programokban olvashatnak az érdeklődők. Ugyanakkor ezek fejlesztésével nem szabadna leállni a végrehajtói munkavégzés során sem. Sajnos, most úgy tünik, hogy ez a folyamat a tiszthelyettesi avatáskor megszakad. Magától értetődően bizonyos eltérések korábban is voltak és ez után is lesznek a szakterülettől függően az érintett kompetenciák értékét illetően. Azt akarom ezzel mondani, hogy kicsit más lehet az egyes kompetenciák értékeinek nagysága/fontossága a közrendvédelmi, határrendészeti, bűnügyi,- avagy csapatszolgálati végrehajtók esetében! Persze ezek megszületéséhez komolyabb felmérésekre, vizsgálatokra volna szükség. ${ }^{19}$

Az elvárások és a korosztályi jellemzők összevetése, az ezekből adódó lehetséges teendők

Ha az előző részben leírt szervezeti elvárásokat összevetjük a két generáció jellemzőivel, akkor ezek elemzése kapcsán több gondolat fogalmazható meg. Jelen esetben ezekből is elsősorban csak azokat érintem, amelyek a rendőri szervezet létszámhelyzetéhez, az utánpótláshoz, továbbá az állomány megtartásához kapcsolódnak, illetve ezzel vannak összefüggésben. A korábbi fejezetrészekben érintett alapinformációk felsorolása után többféle kérdést lehetne feltenni a tárgyalt témát illetően. Jómagam jelen esetben csak egy alapvető kérdést teszek itt fel. Miket volna célszerü tenni, korszerüsíteni, módosítani a rendőrségi végrehajtó állomány legújabb generációból történő utánpótlása és a közülük bekerültek megtartása érdekében?

A kapcsolódó kérdésre adandó válaszoknál a két korosztályi jellemzőkből és a jelenlegi szervezeti elvárásokból indulok ki. Azokból, amelyek ma még lehet, hogy igazak, valósak, de holnap talán már nem fognak az akkori helyzetnek is megfelelni.

Először is azzal kezdem, hogy nagy gondnak tartom e szervezet érvényes humán stratégiájának ehhez kapcsolódó cselekvési tervnek a hiányát. A rendvé-

19 Ezt annak ellenére mondom, hogy tudom: Dr. Malét-Szabó Erika r. alezredes vezetésével jelenleg folyamatban van a KLIR rendszer kialakítása, illetve a kompetenciák felmérése. 
delmi szervek sikeres működése egyik előfeltétele az ágazatban érvényes - a jövőkép alapján álló - színvonalas humánerőforrás stratégia megléte, az abban megfogalmazottak naprakész megvalósítása. Ennek hiányát sürgősen - a várható jövő humán oldalról történő sokoldalú, tudományos elemzését követően - pótolni szükséges. Itt jegyzem meg, hogy a szervezeten belüli szolgálati ágak, szolgálatok és szakszolgálatok jól felkészült képviselöiből álló csoportoknak, projektmunka keretében azt is elemezni, prognosztizálni kellene, hogy milyen lesz a szervezeti elemek jövőbeni müködése majd a 2020-as, 2050-es évek során. Hol, milyen részterületeken veheti majd át a mesterséges intelligencia, a robottechnika a hagyományos emberi erőt, tevékenységet. Ugyanis az ezekre vonatkozó jó előrejelzések igazíthatják a humánerőforrás további igényeit, minőségét, mennyiségét. Sőt az akkor dolgozó rendőr szakmunkára vállalkozók jelenleg érvényes kompetenciáit is átírhatják. Ha ezt nem tesszük, akkor csak kullogunk az események után és nem tudatos elötervezést érvényesítünk.

A toborzás korábban nagyon megfelelt módszertana már kevés lehet ahhoz, hogy az érintett korosztályi jellemzőket kompenzálja. Hol és hogyan, milyen módon történjen a toborzás?

A középfokú rendészeti szakközépiskolák/szakgimnáziumok korábban és jelenleg is alkalmazott, jól bevált nyíltnapjain, a tanulók korábbi civil iskolájukba történő visszaküldésén túl a legújabb - főleg a $Z$ generáció tagjai részére - új színtereket is meg kell próbálni. Ilyenek lehetnek például; az interaktív portálok, iPadok, okos telefonok, virtuális marketingalkalmazások. ${ }^{20} \mathrm{~A}$ toborzásoknak olyan helyen is célszerü történnie, ahol az iskolai időn kívül a legtöbben vannak fiatalok, így például a nagy plázákban, bevásárlóközpontokban. Arra is figyelni kell, hogy a szórólapok, egyéb anyagok hogyan néznek ki. Mivel a fiatalok számára fontos a külső, a vonzó tartalom, ezért kiemelt jelentősége van egy-egy plakát megtervezésének, egy jól megvágott videónak stb. Ugyanakkor az is nagyon fontos, hogy a kapott anyag, információ hiteles legyen. Ehhez persze arra is szükség volna, hogy a szervezet a kommunikációs stratégiáját is átgondolja, illetve a saját magával szemben támasztott elvárásokat. Fontosnak tartom - a megalkuvás nélküli - a komplex, jól megalapozott és föleg hiteles, igaz kommunikációt. Nem szabad csak a fiatalok kalandvágyára építeni, csak arról beszélni, amit ők hallani szeretnének. Fontos lenne kiemelni ennek során a segítő rendőrség képét. Ez a korosztály látott már önkéntes munkát, és már

20 A célzott marketing lassan elengedhetetlen e korosztály eléréséhez. Csak azok fognak a rendőrség honlapján tájékozódni, akik mindenféleképpen rendőrök szeretnének lenni, de felugró ablakokkal, célzott reklámokkal más érdeklődőket is meg lehetne szólítani. Talán az sem ördögtől való gondolat, hogy bízzuk profi állásvadászokra, HR szakemberekre a toborzást. A határvadász toborzás költségeit látva ez sem lenne drágább. Európai rendőrségeknél ez már bevett gyakorlat. 
végez is ilyet ${ }^{21}$. Szerintük trendi dolog ilyen kalandokban részt venni. Számukra legalább olyan fontos a megtalált kerékpár visszaadása, a tüzből és balesetből az érintett személyek és állatok kimentése, az eltévedt kisgyerek megtalálása, mint a mindennapi rend, a közlekedés szabályainak kérlelhetetlen betartása, betartatása. És nagyon fontos: ezekről ne olyan esetlen módon tegyünk közzé híreket, ahogy szoktunk. Erre áldozni kell. Legyen figyelemfelkeltö, rövid, jól fényképezett, forgatott anyag. Ez érdekli a fiatalokat, ezt tudják emészteni. A toborzás mellett legalább ilyen fontos a szervezetben már bent lévők megtartása is. ${ }^{22}$

Amennyiben képtelen az adott szervezet munkavállalói megtartására, akkor ezt még erősebb toborzással - avagy technológiai fejlesztéssel, digitalizálással, esetleg bizonyos mozzanatok automatizálásával - kellene kompenzálnia. (Lásd például a Roboder-t.) Egyébként pedig bekövetkezik az, amikor adott szervezet, szervezeti elem a szükségesnél kisebb létszámmal kénytelen túlóráztatásokkal eleget tenni rendeltetésének. (2017 első félévében összesen 1,68 millióval több túlórát teljesített a hivatásos állomány, mint a menekültválság kezdetén, azaz 2015 első félévében.) A szervezetnek azt is fel kell(ene) ismernie, hogy a létszám önmagában nem jelenti a tudás meglétét is. A tudásmenedzsment is nagyon fontos lehet, a már régóta a pályán lévőknek pedig potenciálisan egy plusz motivátor lehetne, ha átadhatnák a szakmaiságukat olyan fiataloknak, akik arra valóban nyitottak, akik valóban át szeretnék venni a stafétát. A mentori rendszer erre akár alkalmas is lehetne, föleg, ha a mentorok valamilyen szinten kiemelésre is kerülnének. Ugyanakkor vannak olyan ösztönzők is, amelyeket a szervezet korábban adott, jelenleg viszont valamiért hanyagol, vagy nem arányosan ítél meg, pl.: utazási költség támogatása, lakhatás támogatása.

Ide kapcsolódik az aktív hivatásos vezetôi állomány által sokszor előkerülő polémia. Kell-e a rendőri munkának államilag elismert szakmának lennie, kell-e ennek a köznevelés, szakképzés, a felnőttképzés hatálya alá tartoznia, ezek általi legalapvetőbb szabályaikat alkalmazni rá? Ha csak egy kicsit is fontos a társadalmi elismertség, akkor ez a kérdés fel sem merülhet! A képzés időtartama, tartalma, metodikája lehet kérdés, de a jogszabályi kontroll és minőségellenőrzés az semmiképpen sem! Nem visszafelé, hanem elörefelé kell elmozdulni. Ez a generáció nem tekinti kihívásnak, az olyan munkát, elfoglaltságot, amelyhez bármilyen képzésben, betanítói szinten hozzá lehet férni.

21 2016.01.01-töl az 50 órás közösségi munkavégzés az érettségire bocsátás feltétele.

22 Fontos számukra a társadalmi elismertség. Semmiképpen nem kívánnak olyan munkát végezni, amit a közösség nem ismer el, nem tekint fontosnak. E tekintetben van még javítani valónk. Sokatmondó adat, hogy az iskola rendszerủ képzésbe jelentkezők jelentős része a társadalom alacsonyabban rétegeiből kerül ki, jövedelmi viszonyaik erősen korlátozottak. 
Mind a toborzás, mind a megtartás szempontjából van egy olyan tényező, ami ma, ebben a versenyhelyzetben alapvetően meghatározó. Ez pedig az anyagiak, ebböl is az alapbér, majd közvetlenül utána az egyéb kiegészítő juttatások. Amennyiben a szigorú, sokoldalú elvárásokkal, kötöttségekkel nincsenek arányban az anyagi juttatások, akkor ez negatív következményt eredményez az állomány utánpótlásában, megtartásában. Mindenekelőtt nézzük az országos átlagszámokat, amely azt mutatja, hogy a bruttó 329.900 forint volt 2018-ban az átlagkereset, ami nettó 219.400 forintot, és 11,3 százalékos béremelkedést jelent: derül ki a KSH jelentéséből. 2018.01-11. hó között az előző év ua. időszakához képest mindkét adat 11,5 százalékkal magasabb lett. Feltehető a kérdés vajon mi a helyzet a rendvédelmi szervek hivatásos állománya esetében. Az életpálya bevezetése után a tisztek havi átlagkeresete 2015 végén 414.533, az altiszteké 285.886 forint bruttó volt. Egy pályakezdő rendőr őrmester alapbére az elmúlt évben (a kétéves rendőriskola elvégzése után) havi bruttó 220.305 forint, kb. $150.000 \mathrm{ft}$ nettó. Erre persze jöhet még valamilyen pótlék pár tízezer forintban.

Különösen fontos lenne a fiatal pályakezdők lakhatása szempontjából érzékelhetö javulást elérni általában, és különösen azoknál, akik nem lakhelyükön szolgálnak. Itt talán megoldást jelenthetne a korábban bevált szolgálati - speciális esetekben készenléti, beosztással járó - lakások, nőtlen szállók építése, vagy a fizetés rendfokozatra, beosztásra való tekintettel lakhatási pótlékkal történő kiegészítése.

Az állomány megtartása érdekében a munkáért kapott járandóságon (benne mindenen) túl nem lényegtelenek az adott munkahelyi körülmények, életviszonyok. Az adott munkahely - milyenségétől függően - sokat tehet a kezdő kollégák beillesztésébe, hozzáállása alakításában, megtartásában. Ide tartozik adott szervezetnél dolgozó generációk milyensége, összetétele, egymáshoz való viszonyulása, a felszabadult munkahelyi légkör, a csapat, amelyben együtt dolgoznak, a munkatársak és a vezetők közötti viszonyok. De a pályát az itt dolgozók számára is újra vonzóvá kell tenni! Itt említem meg adott szervezeti elem aktuális generációs korfája szükségességét is. (Meretei, 2017, 10-18.)

Mivel a Z generáció tagjai - hasonlóan az Y- hoz - leginkább a saját álmaik és vágyaik után mennek inkább, őket már nehezebb integrálni a szervezetbe, mert ha ezekben korlátozva érzik magukat, akkor inkább továbbállnak. Valószínüleg az információs kor szülötteinek többsége ezt a fajta önmegvalósító munkamorált fogja választani. A téma szakértői szerint a jövőben jobban kell számolni olyan munkavállalókkal, akik - ellentétben a régiekkel - már kevésbé engedik, hogy megmondják, mit és hogyan csináljanak, és nemigen tartják be a vonatkozó elöírások minden betüjét. Ugyanakkor nem elképzelhetetlen, hogy megtennék, ha annak egyértelmü és jól kommunikált célja lenne. Miért gond ez? 
Azért, mert jelenleg a rendvédelmi szervek teljes körénél érvényes a szolgálati hierarchia, a parancsadás és végrehajtás összhangja. Lehet, hogy már az is pozitív hatással bírna e kérdéskörben, ha az egyértelmű szakmai feladatszabáson túl, élhetnének minimális diszkrecionális jogokkal a végrehajtásban dolgozók. A Z generáció tagjai - még az X-töl is jobban - szeretik, ha a beosztottak és a főnökség között nyílt kommunikáció folyik. Fontos, hogy figyelembe vegyék a véleményüket és mindig kapjanak visszajelzést saját vezetőiktől. Méltányolandó a szervezetek jól összerakott team munka jellegü müködése. Szerintem a különféle projektekben való dolgozás jellemző lesz a rendvédelmi szervezetek esetében is. Egy-egy egyedi feladatra alkalomszerüen kellene bizonyos teameket létrehozni, müködtetni, majd pedig a teljesítés után megszüntetni. Erre egyedi példák egyébként már vannak. (Besenyei, 2016, 3.)

A vezetőket és a munkatársakat egyaránt érinti az a jellemző, hogy számukra már nem a kortól függ valakinek a hitelessége, hanem attól: mit tett le az illető az asztalra. Az új belépők vajon mit tudnak kezdeni ezzel a jellegéből adódóan hierarchikus, parancs-uralmi rendszerrel? Miként alakul esetükben a tekintély, hiszen az értelmezésükben a tiszteletet mindenkinek ki kell érdemelnie. Vajon lehet-e ebbe olyan rugalmasságot csempészni, ami a fiatalok hosszú távú megmaradását, mi több: a boldogságát is elsegíti úgy, hogy a szervezet alapvető jellege, a feladatok teljesítési kötelessége továbbra is érvényesül?

Felmerülhet a kérdés, hogy a szervezet munkatársaitól napi munkavégzésük során mennyire, illetve milyen mértékben várják el az innovatív, újszerü gondolkodást, a kockázatvállalást, ha szükséges, a rámenős magatartást. A rendvédelem esetében nehéz arra egyértelmú és megalapozott választ adni, hogy az érintett szervezeti kultúrákat a kockázatvállalás vagy inkább a kockázatkerülés értékorientációja hatja-e át.

További fontos szempont a karrierlehetőségek milyensége. A jelenlegi szabályozás szerint 8 évet is kell várni az előrelépésre. Mindezt egy alapvetően türelmetlen, tettre kész generációtól várjuk el. Semmiképpen sem szabad, hogy ez csak és csupán kapcsolat kérdése legyen, hanem sokkal inkább győzzön a jobbik elvének átlátható, egyértelmü érvényesítését jelentse. De ide kapcsolom azt a már korábban is feltett kérdést is, hogy miért akar az altisztek nagy része tiszt lenni? ${ }^{23}$ Azért, mert egyrészt az jobban fizetett, másrészt pedig azért, mert számára más karrier ív nemigen van.

A közterületi rendőri munka, illetve ennek milyensége, kiszámíthatósága kevésbé tervezhető előre. E vonatkozásban a lehetőségek határain belül nagyobb

23 Vannak persze olyanok is, akik azért nem vágnak bele a felsőoktatásba, mert mások, már több éve meglévő diplomájukkal nagyon sokat várnak a tiszti kinevezésre, ami kedvét szegheti a többieknek is. 
kiszámíthatóság szükséges a szolgálattervezésben, ennek gyakori változtatásában megfontolandó teendői lehetnek az illetékes vezetőknek. Amennyiben a szolgálati feladatok és a magánélet összeillesztésének lehetősége adott helyen nem lesz megoldható az érintett generációk esetében, ne csodálkozzon az illetékes vezető a nagyobb fluktuáción.

Egy bizonyos nemzetközi tanulmány szerint a munkahelyen inkább mentorokra vágynak az új generáció tagjai olyanokra, akikkel nyíltan lehet beszélniük, nemcsak szakmai problémákról. A rendőrségi korfa és a kisebb létszámú munkaerő sajnos ennek nemigen tud pozitívan megfelelni. A korábban létezett mentori szerep is át fog alakulni az egy irányúból, a kétirányúba.

Azzal is számolni kell, hogy a tekintélyhez való viszony megváltozik és az iskolai szituációban hagyományos módszertani kultúra mellett a tudásszerzés folyamatában komoly problémák kialakulását hozhatja magával. Amire viszont az iskolának kellene nagyobb figyelmet fordítani, ez az információk elemzése-értékelése, a jó és rossz elkülönítése, az igaz és hamis kiszürése képességének kialakítása, megerősítése, a „világ dolgaiban” való jó eligazodás, valamint a kritikus szemlélet és a kezdeményezőkészség, innováció elemi készségeinek alakítására, erösítésére. Még ha esetleg nincs is most szüksége erre adott szervezetnek. Sokkal nagyobb - életszerü példákkal megtámogatott - gyakorlatiasságra is szükség van/volna. Az előbbieken túl erősíteni szükséges az önállóságra törekvést, a helyes konfliktus-kezelést, az asszertivitást is.

A jövő igényei között nő a jelentősége a gyors reagáló-, tanulási képességeknek, ehhez pedig, ismerni és támogatni szükséges az alkalmazottak kompetenciáit. A várható jövő kihívásaira történő reagálás érdekében rövid, célirányos képzési programokra van szükség az adott munkaterületen kívánatos szakmai kompetenciák (szaktudás) naprakész fejlesztése, a gyors változások megelözése érdekében. A jövőben még nagyobb lesz az LLL jelentősége, a permanens önképzésnek - nyilván már nemcsak hagyományos módon - hanem a korszerü technológia igénybevételével, valamint nemcsak iskolai keretek között.

Mivel e generációk tagjai a változatos feladatokat igénylik, természetesen külön öröm számukra, ha ehhez teret és szabad kezet is kapnak. Ugyanakkor fontos, hogy keretek is legyenek. Itt a szervezetnek és a parancsnoki állománynak is jól kell tudnia mérlegelni és meghúzni a „kemény határokat”. Tudom, ennek alakítása leginkább magától az élettől függ, de azért a vezető is hozzájárulhat ehhez valamilyen mértékben.

Az, hogy jól felszerelt, esztétikus környezetben dolgozzanak fontosabb számukra, mint a szervezet hírneve, ismertsége, bár az is nagy jelentőséggel bír. Vajon a szolgálati helyiségek, a szolgálati gépjármüvek, vagy az egyenruhák képi világa terén volnának-e további javítási lehetőségeink? 
Egyes szakértők szerint a $Z$ generáció tagjai kevésbé preferálják az otthoni munkavégzés lehetőségét az irodaival szemben, amelynek oka - a magyar és külföldi tanulmányok alapján - vélhetően az, hogy sokkal inkább prioritás számukra a munka és magánélet szétválasztása. Ebben én más véleményen vagyok. Ott, ahol a munkakör jellege miatt lehet, ott nincs feltétlenül szükség a hagyományos irodai körülményekre, ami elvégezhető otthon is, akkor erre célszerü lehetőséget biztosítani, az adat- és titokvédelmi szabályok betartásával. Nagyobb lehetőséget kellene mutatni a rendvédelmi szervezeteknél is a részmunkaidős alkalmazásra, különösen hölgyek esetében. Fontos lenne elgondolkodni azon is, hogy milyen alternatívákat tudunk kínálni az idősebb munkatársak számára, ha fizikai/egészségi állapotuk már nem teszi lehetővé a közterületi nappali/éjszakai váltott szolgálatot. Ami fiatalon, a pálya elején még izgalmas, az később, akár a családalapításkor, súlyos kérdés lehet, hogyan fogom ezt bírni x évesen/x betegséggel, vagy éppen tud-e segíteni rajtam a munkahelyem, ha egyedülálló szülővé válok a gyermekemmel.

Sok más szervezettel egyetemben a rendörség - néhány részterület kivételével - kevésbé tudja megteremteni, a kívánatos technológiai hátteret. Pedig sokszor mondjuk, hogy a bünüldözésnek, egy lépéssel mindig előrébb kell járnia a jogsértők elött, az alkalmazott eszközöket illetően. Törekvések természetesen vannak, föleg bünügyi területen, de akárcsak az oktatás keretein belül, itt is elmondható, hogy ma már a magánéletben használt eszközök egy része modernebbek lehetnek, mint a munka során alkalmazottak. Kívánatos a 4. ipari forradalomhoz igazított technikai-technológiai fejlesztések megvalósítása, a monotonnak ítélt tevékenységek kiváltása a jövőben.

Azt is megemlítem, hogy a digitális technika eszközrendszerének birtoklása az egyén és a környezete kapcsolatát forradalmian megváltoztatja. Ennek kapcsán - az online világban eltöltött magas tartózkodási idő miatt - a valóságos világban hiányos konfliktuskezelési készségük,- indulatkezelési nehézségük miatt valamilyen negatív hatás is valószínüsíthető esetükben. Ezen a pályán, ahol jó konfliktuskezelésre a szakma jellege miatt is nagy szükség van, gondot okozhat a szervezet tekintélyében. Ezért is célszerü vele kiemelten foglalkozni már az iskolában is, de különösen a mindennapi végrehajtásban.

A legújabb korosztály kiváló tulajdonságain túl, számolni lehet náluk a környezettől való elidegenedéssel és azzal, hogy virtuális közösségi létük okán több negatív tapasztalattal kell megbirkózniuk, amely nehéz megfelelést, társtalanságot, kiúttalanságot, rohanást és a sikerhajszolást teremthet körükben. Lehet, hogy e korosztály a legveszélyeztetettebb a magányra, szorongásra és agresszióra. De az is előállhat - mivel a virtuális világgal megosztják gondjaikat - hogy szolgálati jellegü titkok, vagy más számunkra kedvezőtlen infor- 
máció kerül rosszhiszemű személyek birtokába, amivel azok visszaélnek. Ezek egyike sem jó. Ilyen jelekre a környezetnek, az illetékes vezetőknek, munkatársaknak érzékeny módon - személyi identitását nem megzavarva - számolniuk, illetve segíteniük kell.

Nem mellékes a jövőben a szervezeti kultúra milyensége, amely alakul magától is, de jó irányú változtatása tudatos beavatkozásokat igényel az adott szintú vezetőktől. Nem egyszerü folyamat az, amíg az un.,„Én - Én” identitás felállásból „Én - Mi” formáció lesz! A szervezeti kultúra egy rendvédelmi alrendszer esetében is, ezen belüli közösen támogatott alapeszméket, értékeket és közösségi filozófiát jelenti. Adott szervezet alkalmazottai esetében a szervezeti kultúra lényeges tényező a saját munkakörük és felelősségük motivációjához és azonosításához.

$\mathrm{A} Z$ generáció egy nagyobb része nem tud mit kezdeni a hivatástudat kifejezéssel. Számukra az érdekes munka létezik, amely kielégíti a kíváncsiságukat, élmény dús, és eléggé izgalmas ahhoz, hogy másnap is ezt kívánják végezni. Ha hosszabb távon tervezünk velük, akkor változatos munkaköröket kell kitalálnunk, és ráadásul azok között rotálni is célszerủ lenne őket az érdeklődésük fenntartása érdekében. Úgy vélem be kell érnünk azzal, hogy a pálya kezdetén szimplán csak egyszerü munkának tekintik e szakmát, és ha sikerül identitásukat célirányosan alakítani, őket a szervezetben tartani, akkor van remény arra, hogy hivatásként müveljék azt. Lassan nyilvánvalóvá válik, hogy általában a szervezetnek is alkalmazkodni kell a leendő munkavállalóihoz, ha nem akar munkaerő nélkül maradni!

\section{Befejezés}

A 21. század technikai, technológiai lehetőségei rohamosan bővülnek, a munkavállalók újabb generációi jelennek meg magasabb igényekkel, más látásmóddal, változó munkavállalói magatartással. A szervezet eredményeinek javulása tartósan leginkább a humánerő fejlesztése révén valósítható meg. Ez a rendvédelmi szervek egyik kiemelt erő tartaléka. A rendőrség jövőbeni szervezetének igazodnia kell mindazokhoz a kihívásokhoz, változásokhoz, követelményekhez és elvárásokhoz, az utánpótlás éles változásaihoz, amelyek egy részéről ezen írás is szól. Fontos, hogy az adott generációk a rendvédelmi szervezeteknél is megtalálják a kapcsolódást, nyitottak legyenek egymás gondolataira, ne csak az eltérésekre, hanem főleg az azonosságokra alapozzanak. Ennek érdekében szakítani kell a csupán adminisztratív dominanciájú személyzeti munkával, nagyobb figyelem kell az emberi erőforrások jó ismeretére, hatékony kihaszná- 
lására. Az új generációk megjelenése egyfajta tükröt tart/tarthat a szervezet elé saját müködésükről, ha erre nem reagál adott szintü döntéshozó, akkor ez nem erősíti tekintélyét. Az új generációk integrálásának kérdése, a már bent lévők megtartása egyfajta küzdelemhez hasonlítható, amelynek többféle kimenete lehet. Ha időt szánunk a fiatalabb generáció megismerésére, kitalálhatjuk azokat a lehetőségeket, amelyek reformálják a szervezeti elvárásokat, tudatosan alakítjuk elöre úgy a körülményeket, amelyek segíthetik a végrehajtó hivatásos állomány utánpótlását, akkor talán sikeresebbek lehetünk. Érdemi, stratégiai alapú, összehangolt változtatásra van szükség. Persze tisztában vagyok vele, hogy a gondok valamilyen szintü írásos felvázolása könnyebb, mint ennek megoldása. Bízom abban, hogy felvetéseim visszhangra találnak, felkeltik az illetékesek érdeklődését és valami célirányos intézkedést is kiváltanak.

\section{Felhasznált irodalom}

Besenyei L. (2016): A generációváltás forradalma. Opus et Educatio, 3.

Bittner Z. - Kehl D. - Szőcs K. (2013): Az országos megkérdezés eredményei. Pécs: TÁMOP-4.2.3-12/1/KONV-2012-0016

Borbély Zs. - Fridrich A. C. - Tőzsér E. (2018): A XXI. század biztonsági kihívásai a rendőrségi szervezeti kultúrában: generációk a szervezetben. Pécsi Határőr Tudományos Közlemények, 97-102.

Borbély Zs. - Fridrich A. C. - Tőzsér E. (2018): Az ideiglenes Biztonsági Határzár menti feladatellátás hatása a határzárat védők magánéletére. Honvédségi Szemle, 6, 65-79.

Ferencz A. - Szabó Zs. R. (2012): A Z Generáció menedzsmentje. Munkaügyi Szemle, 2.

Kissné András K. (2014): Generációk, munkaerőpiac és a motiváció kérdései a 21. században. HR online Magazin

Magyar Értelmező Kéziszótár (1972): Budapest: Akadémiai Kiadó, 997.

Magyar Statisztikai Évkönyv (2016): Budapest: Központi Statisztikai Hivatal, 406.

Meretei B. (2017): Generációs különbségek a munkahelyen - szakirodalmi áttekintés. Budapest: Management Review, 10, 10-18.

Monostori J.- Öri P.- Speder Zs. (szerk.) (2018): Demográfiai portré. Budapest: KSH

Nagy Á. (2017): Az Alfa generáció magyarországi recepciója. Kultúra és Közösség, 3, 53-60.

Sallai J. (2013): A globalizáció rendészeti kihivásai. In: Gaál Gy. - Hautzinger Z. (szerk.): Tanulmányok „A változó rendészet aktuális kihívásai” címü tudományos konferenciáról. Pécs: Magyar Hadtudományi Társaság, 37-41.

Szakács G. (2015): Stratégiai alapú, integrált emberi erőforrás gazdálkodás bevezetésének lehetöségei a magyar közszolgálatban. VII. Országos Tanácsadói Konferencia tanulmánykötete Tari A. (2010): Az Y Generáció. Budapest: Jaffa Kiadó 
Tari A. (2011): A Z generáció. Budapest: Tericium Kiadó

Tari A. (2017): Bátor generációk. Budapest: Tericum Kiadó

Tegyey A. (2018). Az egyes generációk motiválhatóságának kérdései. III. Turizmus és Biztonság Nemzetközi Tudományos Konferencia Tanulmánykötet

Tegyey A. (2018): A Z generáció címke - Jogos félelmek vagy lehetöség a megújulásra? Rendörségi Tanulmányok, 3.

Tegyey A. (2019): Generációk a rendörségen - erösségek, lehetöségek, gyengeségek és veszélyek. Rendészet - tudomány - aktualitások. A rendészettudomány a fiatal kutatók szemével. Konferenciakötet, 234-241.

Töröcsik M. - Szücs K. - Kehl D. (2014): How Generations Think: Research on Generation Z. Acta Universitas Sapientiae, Communicatio, 1, 23-45.

Tőzsér E. - Fridrich A. C. - Borbély Zs. (2017): Ügyfélszolgálati szemlélet a szervezeti kultúrában. II. Turizmus és Biztonság Nemzetközi Tudományos Konferencia Tanulmánykötet, 119127. http://uni-pen.hu/files/konferencia/2017/Teljes_konf_tanulmanykotet.pdf

\section{A cikkben szereplő online hivatkozások}

URL1: https://ec.europa.eu/eurostat/web/products-eurostat-news/-/DDN-20190104-1

URL2: 1994. évi XXXIV. törvény a rendőrségről 4.§ https://net.jogtar.hu/jogszabaly?docid $=99400034 . T \mathrm{~V}$ 